\title{
Aktivitas Antimikrob Fraksi Ekstrak Etanol Buah Pinang (Areca catechu L) pada Bakteri Methicillin Resistant Staphylococcus aureus
}

\author{
Perdina Nursidika, ${ }^{1}$ Opstaria Saptarini, ${ }^{2}$ Nurul Rafiqua ${ }^{3}$ \\ ${ }^{1}$ Program Studi Analis Kesehatan, Sekolah Tinggi Ilmu Kesehatan Jenderal Achmad Yani \\ ${ }^{2}$ Fakultas Farmasi Universitas Setia Budi Surakarta, ${ }^{3}$ Fakultas Farmasi Universitas Padjajaran
}

\begin{abstract}
Abstrak
Infeksi merupakan penyakit penyebab kematian di Indonesia. Salah satu penyebab perkembangan penyakit infeksi di Indonesia adalah resistensi bakteri terhadap antibiotik standar. Methicillin resistant Staphylococcus aureus (MRSA) merupakan penyebab utama infeksi nosokomial dan komunitas. Telah dilakukan uji aktivitas antimikrob fraksi dari ekstrak etanol buah pinang (Areca catechu L) pada bakteri MRSA. Penelitian dilaksanakan di Laboratorium Mikrobiologi Stikes Jenderal Achmad Yani Cimahi, Laboratorium Farmakologi Institut Teknologi Bandung, dan Laboratorium Pusat Penelitian dan Pengembangan Geologi Kelautan Bandung pada Mei-Juni 2011. Aktivitas antimikrobekstrak dan fraksi diuji menggunakan metode broth microdilution, bioautografi, dan scanning electron microscope (SEM). Hasil pengujian menunjukkan bahwa fraksi yang paling efektif ialah fraksi air dengan minimum inhibitory concentration (MIC) $256 \mu \mathrm{g} / \mathrm{mL}$. Hasil bioautografi menunjukkan bercak kromatogram kromatografi lapis tipis (KLT) yang memberikan hambatan terhadap bakteri uji adalah bercak dengan Rf 0,6. Bercak ini diduga merupakan senyawa fenolat karena memberikan hasil positif dengan penyemprotan $\mathrm{FeCl} 3$. Hasil SEM menunjukkan bakteri uji yang telah dipapar dengan tanaman uji diduga mengalami kerusakan pada membran atau bagian yang lebih dalam, sehingga sel bakteri menciut dan bergelembung hingga rusak.Simpulan, ekstrak etanol buah pinang dapat menghambat pertumbuhan bakteri MRSA. [MKB. 2014;46(2):94-9]
\end{abstract}

Kata kunci: Aktivitas antimikrob, Areca catechu, microdilution, MRSA, SEM

\section{Antimicrobial Activity of Betel Nut Ethanolic Extract Fractions in Methicillin Resistant Staphylococcus aureus}

\begin{abstract}
Infection is the major cause of death in Indonesia. Antibiotic resistant is responsible for this progression. Methicillin resistant Staphylococcus aureus (MRSA) is known as the main cause of nosocomial and community infections. The antimicrobial activity of ethanolic extract fractions of betel nut (Areca catechu L) was studied on MRSA. The research was performed at the Microbiology Laboratory, School of Health Sciences, Jenderal Achmad Yani University, Cimahi, the Pharmacology Laboratory of Bandung Institute of Technology, and Research and Development of Ocean Geology Laboratory in May-June 2011.The antimicrobial activities of the extract and fraction were tested by microdilution broth method, bioautography and scanning electron microscope (SEM). The most effective result showed by water fraction with minimum inhibitory concentration (MIC) was $256 \mu \mathrm{g} / \mathrm{mL}$. Bioautography result showed a spot on thin layer chromatography (TLC) chromatogramof water fraction which inhibited the bacterial growth, which was the spot with $\mathrm{Rf} 0.6$. The spot was suggested as a phenolic substance due to positive result to $\mathrm{FeCl} 3$. The electron microscope image showed the breakdown of membrane cell/inner site of bacteria which was exposed by betel nut extract and fractions in which the bacteria was shrinked, bubbled and broken.In conclusion, betel nut ethanolic extract has the ability to inhibit MRSA. [MKB. 2014;46(2):94-9]
\end{abstract}

Key words: Antimicrobial activity, Areca catechu, microdillution, MRSA,SEM

Korespondensi: Perdini Nursidika, M.Si, Program Studidi Analis Kesehatan, Sekolah Tinggi Ilmu Kesehatan Jenderal Achmad Yani Jalan Terusan Jenderal Sudirman Cimahi 40533, mobile 085221687459, e-mail perdina@analis-ayani.ac.id 


\section{Pendahuluan}

Penyakit infeksi merupakan salah satu penyakit yang banyak menyebabkan kematian di seluruh dunia, termasuk Indonesia. Data World Health Organization (WHO) menyatakan bahwa pada tahun 2005 penyebab tertinggi kematian anak $<5$ tahun di Indonesia disebabkan oleh penyakit infeksi. ${ }^{1}$ Penyakit infeksi di Indonesia semakin meningkat pada setiap tahunnya akibat beberapa faktor penyebab, misalnya kesadaran masyarakat akan kebersihan yang kurang, kurangnya petugas kesehatan yang terlatih, jumlah penduduk yang padat, kurangnya pengetahuan dan implementasi dari sebagian besar masyarakat mengenai dasar infeksi, proseduryang tidak aman, serta kurangnya pedoman dan juga kebijakan dari pemerintah. ${ }^{2}$ Infeksi berkembang menjadi lebih luas akibat penggunaan antibiotik yang dipergunakan tidak tepat dalam segi dosis dan kurangnya informasi empiris tentang penyakit infeksi sehingga hal ini menyebabkan bakteri menjadi resisten., ${ }^{3,4}$

Bakteri menjadi resisten terhadap antibiotik karena bakteri dapat mengurangi atau bahkan menghilangkan efektivitas antibiotik. Resistensi terjadi akibat mutasi genetik pada bakteri. ${ }^{5}$ Saat ini sudah banyak diketahui mikrob resisten, termasuk methicillin resistant Staphylococcus aureus (MRSA), methicillin resistant coagulase negative Staphylococcus (MRCNS), dan juga vancomycin resistant Enterococcus (VRE). Methicillin resistant Staphylococcus aureus merupakan penyebab utama infeksi nosokomial dan komunitas. ${ }^{6,7}$

Bakteri MRSA mempunyai faktor virulensi berulang yang dapat membuat bakteri bertahan di dalam kondisi ekstrem ${ }^{8}$ dan epidemiologinya berubah sangat cepat. Resistensi ini semakin berkembang, sehingga dibutuhkan cara/alternatif pengobatan untuk penanganannya. Pengobatan yang memungkinkan untuk mengatasi infeksi bakteri resisten antibiotik ini adalah dengan memanfaatkan senyawa aktif fitokimia. Pada beberapa tanaman, senyawa ini dipergunakan untuk mempertahankan diri dari predator seperti mikroorganisme, serangga, dan juga herbivora. Banyak tanaman yang sudah terbukti secara ilmiah mempunyai aktivitas antimikrob dan dapat menghambat pertumbuhan bakteri. Kebanyakan agen ini memiliki struktur dan aksi yang berbeda dari antibiotik yang biasa digunakan., ${ }^{9,10}$

\section{Metode}

Penelitian ini dilaksanakan di Laboratorium Mikrobiologi Sekolah Tinggi Ilmu Kesehatan Jenderal Achmad Yani Cimahi, Laboratorium
Farmakologi Institut Teknologi Bandung, dan Laboratorium Lembaga Pusat Penelitian dan Pengembangan Geologi Kelautan Bandung pada Mei-Juni 2011. Penelitian ini terdiri atas 4 (empat) tahapan penelitian. Tahap pertama merupakan persiapan ekstrak dan fraksi dengan menggunakan maserasi dan fraksinasi menggunakan berbagai pelarut berbeda kepolaran. ${ }^{11,12}$ Tahap yang kedua merupakan tahap pengujian konsentrasi hambat minimum ekstrak dan fraksi terhadap bakteri uji mempergunakan metode microbroth dilution..$^{13,14}$ Tahap ketiga adalah merupakan tahap pengujian senyawa yang diduga memberikan hambatan terhadap bakteri uji, tahap ini mempergunakan metode bioautografi. ${ }^{15}$ Tahap keempat bertujuan untuk melihat kerusakan bakteri setelah dipapar oleh ekstrak dan fraksi menggunakan scanning electron microscope (SEM). ${ }^{16}$ Kultur bakteri yang digunakan pada penelitian ini adalah MRSA yang diperoleh dari koleksi Laboratorium Farmakologi Institut Teknologi Bandung. Semua bakteri uji ditumbuhkan pada media agar nutrient.

Tanaman uji yang digunakan pada penelitian ini dari Badan Pengembangan Tanaman Obat (BPTO) Tawangmangu Solo dan dideterminasi di Laboratorium Morfologi Sistematik Universitas Setiabudi Solo. Tanaman kemudian dilakukan ekstrak dengan etanol $96 \%$ selama $3 \times 24$ jam memakai metode maserasi. Maserat kemudian diuapkan dengan evaporator untuk menghilangkan pelarut. Ekstrak tersebut kemudian difraksinasi menggunakan corong pisah menggunakan air, heksana, dan etil asetat. Hasil fraksinasi diuapkan untuk menghilangkan pelarut.

Minimum inhibitory concentration (MIC) didapatkan dengan pengujian metode micro broth dilution menggunakan microplate dan media brain heart infussion (BHI) broth (OXOID CM1135). Pada kolom pertama yaitu sebanyak $100 \mu \mathrm{L}$ BHI broth dimasukkan ke dalam pelat mikro sebagai kontrol negatif. Suspensi mikrob sebanyak $5 \mu \mathrm{L}$ ditambahkan ke dalam $10 \mathrm{~mL}$ BHI broth kemudian diaduk dengan alat vorteks. Sebanyak $100 \mu \mathrm{L}$ campuran tersebut dimasukkan ke dalam pelat mikro pada kolom kedua sampai kedua belas. Pada kolom ke-12, ditambahkan $100 \mu \mathrm{L}$ larutan ekstrak kemudian dihomogenkan, diambil sebanyak $100 \mu \mathrm{L}$ kemudian dipindahkan ke kolom ke-11. Pengenceran terus dilakukan sampai pada kolom ketiga yang akan memiliki konsentrasi terkecil. Pelat diinkubasi pada suhu $37{ }^{\circ} \mathrm{C}$ selama 24 jam kemudian diamati bagian yang jernih (tidak ada pertumbuhan mikrob). Konsentrasi terkecil tidak terlihat pertumbuhan mikrob ditetapkan sebagai MIC. Sebanyak $5 \mu \mathrm{L}$ alikuot dari setiap bagian yang jernih dipindahkan dalam nutrien agar dan diinkubasi pada suhu 37 ${ }^{\circ} \mathrm{C}$ selama 24 jam kemudian diamati. Konsentrasi 
Tabel 1 Profil Fitokimia Ekstrak dan Fraksi Pinang

\begin{tabular}{|c|c|c|c|c|c|}
\hline \multirow{2}{*}{$\begin{array}{l}\text { Golongan } \\
\text { Senyawa }\end{array}$} & \multirow[b]{2}{*}{ Ekstrak Etanol } & \multicolumn{3}{|c|}{ Tanaman Pinang } & \multirow[b]{2}{*}{ Fraksi Air } \\
\hline & & Fraksi & n-Heksan & Fraksi Etil Asetat & \\
\hline Alkaloid & + & & + & - & - \\
\hline Flavonoid & + & & - & + & + \\
\hline Saponin & + & & + & + & - \\
\hline Kuinon & + & & + & + & - \\
\hline Tanin & + & & - & + & + \\
\hline Terpenoid & + & & + & - & - \\
\hline Steroid & - & & - & - & - \\
\hline
\end{tabular}

Keterangan: fraksi yang diuji merupakan fraksi dari ekstrak etanol; +: ekstrak mengandung senyawa golongan tersebut; -: ekstrak tidak mengandung senyawa golongan tersebut

terendah tidak terlihat pada pertumbuhan mikrob ditetapkan sebagai minimum killing concentration (MKC). Hal yang sama dilakukan pada bakteri MRSA dengan dipapar antimikrob standar yaitu eritromisin, tetrasiklin, dan penisilin G. Semua konsentrasi antimikrob yang standar sama dengan konsentrasi ekstrak.

Suatu metode bioautografi digunakan untuk mengetahui senyawa yang dianggap efektif dalam menghambat pertumbuhan bakteri. Bioautografi dilaksanakan dengan metode kontak dan agaroverlay. Metode langsung dilakukan dengan cara menyentuhkan pelat thin layer chromatography (TLC) pada permukaan media agar yang sudah ditanami bakteri uji. Sesudah inkubasi selama waktu tertentu maka letak zat aktif antimikrob ditandai dengan terdapat zona jernih dengan latar belakang jernih. Agar-overlay merupakan metode campuran antara metode kontak dan langsung. Antimikrob dalam agar dituangkan pada TLC kemudian TLC yang telah mengandung mikrob diinkubasi selama 24 jam dan dilihat zona bening yang terbentuk di antara noda yang terdapat pada TLC.

Penentuan mekanisme antimikrob dengan metode SEM. Prinsip SEM yaitu gambar dibuat berdasarkan pada deteksi elektron baru (elektron sekunder) atau elektron pantul yang muncul dari bagian permukaan sampel pada saat permukaan sampel tersebut dipindai dengan sinar elektron. Elektron sekunder atau pantul yang terdeteksi selanjutnya akan diperkuat sinyalnya, kemudian besar amplitudonya ditampilkan dalam gradasi gelap-terang pada layar monitor cathoderay tube (CRT). Di layar CRT inilah gambar struktur objek yang sudah diperbesar dapat dilihat. Pada proses operasinya, SEM tidak memerlukan sampel yang ditipiskan, sehingga dapat digunakan untuk melihat objek dari sudut pandang 3 dimensi.

\section{Hasil}

Pemeriksaan kandungan kimia ekstrak dilakukan untuk mengetahui jenis golongan senyawa yang terdapat dalam ekstrak. Hal ini untuk memeriksa kandungan senyawa aktif yang berperan sebagai antimikrob.

Karakterisasi ekstrak dalam penelitian ini bertujuan untuk mengetahui spesifikasi ekstrak yang dipergunakan sebagai bahan baku obat. Karakterisasi ekstrak yang dilaksanakan meliputi penetapan kadar air, kadar sari larut air, dan kadar sari larut etanol

Tabel 2 Hasil Karakterisasi Simplisia

\begin{tabular}{lcc}
\hline \multicolumn{1}{c}{ Karakteristik } & Simplisia & Ekstrak \\
\hline Kadar air $(\% \mathrm{v} / \mathrm{b})$ & 12,48 & 6,9 \\
Kadar sari larut air $(\% \mathrm{~b} / \mathrm{b})$ & 13,86 & 9,26 \\
Kadar sari larut etanol $(\% \mathrm{~b} / \mathrm{b})$ & 24,21 & 36,44 \\
Susut pengeringan $(\%)$ & 24,59 & \\
Kadar abu total $(\%)$ & 4,49 & \\
Kadar abu tidak larut asam $(\%)$ & 1,42 & \\
\hline
\end{tabular}


Tabel 3 Hasil Penentuan Nilai MIC dan MKC Fraksi dari Ekstrak Etanol Buah Pinang terhadap Mikrob Uji

\begin{tabular}{|c|c|c|c|c|c|c|c|c|}
\hline \multirow[t]{2}{*}{ Mikrob } & \multicolumn{2}{|c|}{$\begin{array}{c}\text { F. air } \\
(\mu \mathrm{g} / \mathrm{mL})\end{array}$} & \multicolumn{2}{|c|}{$\begin{array}{c}\text { F. etil } \\
(\mu \mathrm{g} / \mathrm{mL})\end{array}$} & \multicolumn{2}{|c|}{$\begin{array}{c}\text { F. heksan } \\
(\mu \mathrm{g} / \mathrm{mL})\end{array}$} & \multicolumn{2}{|c|}{$\begin{array}{c}\text { Tetrasiklin } \\
(\mu \mathrm{g} / \mathrm{mL})\end{array}$} \\
\hline & MIC & $\mathrm{MKC}$ & MIC & MKC & MIC & MKC & MIC & MKC \\
\hline MRSA & 256 & $>1024$ & 1024 & $>1024$ & 1024 & $>1024$ & 128 & 512 \\
\hline
\end{tabular}

Keterangan: $\mathrm{MIC}=$ minimum inhibitory concentration $; \mathrm{MKC}=$ minimum killing concentration $; \mathrm{MRSA}=$ methicillin resistant Staphylococcus aureus

Setelah dilakukan uji penapisan fitokimia dan karakterisasi ekstrak, juga dilakukan pemantauan ekstrak menggunakan metode kromatografi lapis tipis pada pelat silika gel $60 \mathrm{~F}_{254}$ Eluen yang dipergunakan adalah kloroform:metanol dengan konsentrasinya 4:6. Penampak noda adalah $\mathrm{FeCl}_{3}$ untuk menunjukkan senyawa fenol.

Uji aktivitas dari antimikrob bakteri resisten antibiotik itu dilakukan dengan mempergunakan metode broth microdilution. Hasil uji antimikrob didapatkan konsentrasi minimum ekstrak dan fraksi buah pinang yang dapat menghambat dan membunuh bakteri MRSA.

Hasil bioautografi itu memperlihatkan bahwa bercak noda fraksi air pinang dapat menghambat pertumbuhan bakteri MRSA. Dengan bioautografi dapat dilihat zona jernih yang terbentuk setelah perlakuan dan inkubasi selama 24 jam.
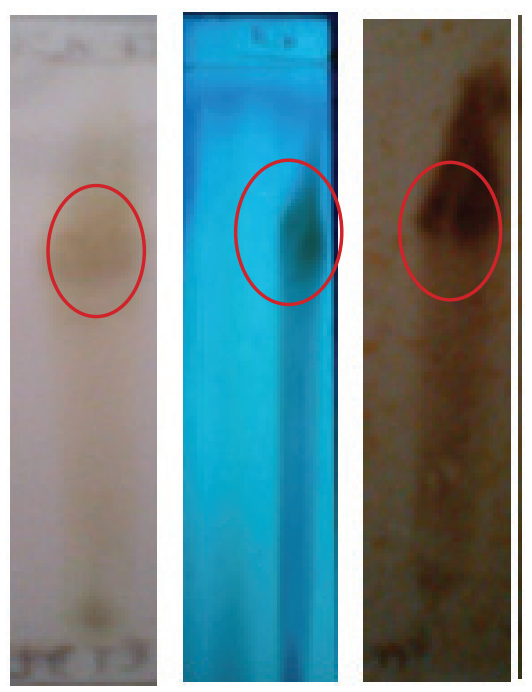

Gambar 1 Pola Kromatogram Fraksi Pinang, Fase Diam Silika Gel 60 F $_{254}$.

(1) Fraksi air pinang, pengembang kloroform:metanol 4:6, (2) Dilihat di $\lambda 254 \mathrm{~nm}$, (3) disemprot dengan $\mathrm{FeCl} 3$ terbentuk noda berwarna ungu kehitaman

\section{Pembahasan}

Pinang telah lama digunakan untuk obat karena mempunyai efek farmakologi yang luas. Efek antimikrob buah pinang sudah diuji pada beberapa mikrob yang ada di mulut seperti Streptococcus mutans, Streptococcus salivarius, Candida albicans, dan juga Fusiform nucleatum. Senyawa dalam buah pinang yang diduga mempunyai efek antibakteri adalah senyawa tanin. Asam tanin dalam berbagai konsentrasi, dari konsentrasi 1,8$18 \mathrm{mg} / \mathrm{mL}$ dapat menghambat pertumbuhan $E$. corrodens, Prophyromonas gingivalis, C. rectus, dan Fusiform nucleatum. ${ }^{17}$

Ekstraksi dilakukan dengan mempergunakan etanol. Etanol itu dapat menarik sebagian besar senyawa polar dan juga sebagian kecil senyawa nonpolar. Setelah didapatkan ekstrak, dilakukan

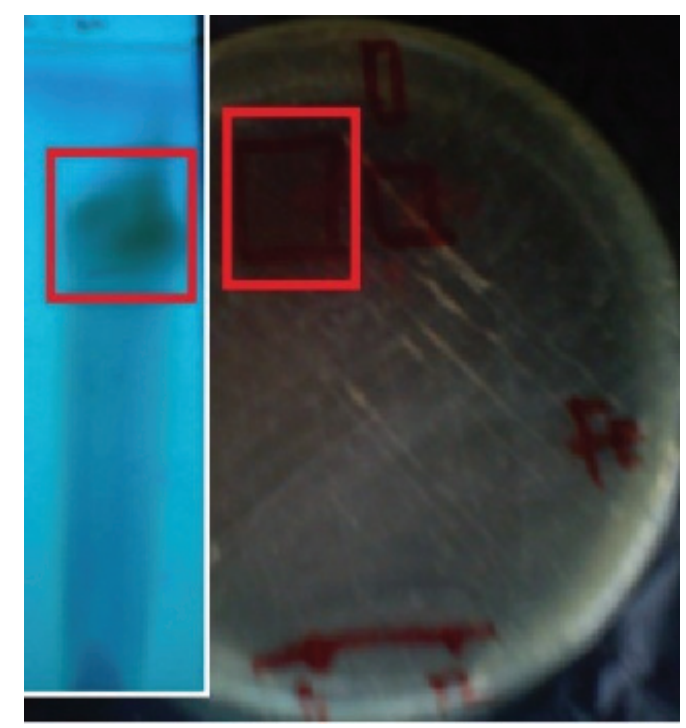

Gambar 2 Hasil Bioautografi terhadap Bakteri MRSA. (1) TLC yang digunakan untuk bioautografi (2) Zona jernih yang terbentuk setelah agar berisi bakteri kontak dengan KLT no. 1 

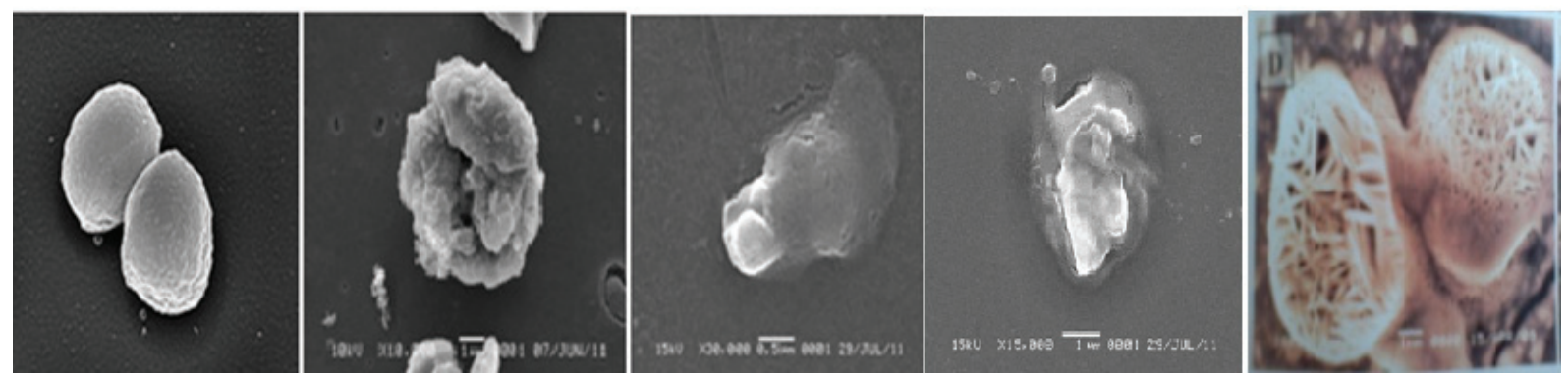

Gambar 3 Hasil SEM MRSA (1) Bakteri MRSA, (2) Bakteri MRSA yang Terpapar oleh Fraksi Air Pinang,

(3) Bakteri MRSA yang Terpapar oleh Eritromisin, (4) Bakteri MRSA yang Terpapar oleh Tetrasiklin, (5) Bakteri MRSA yang Terpapar oleh Penisilin G

fraksinasi terhadap ekstrak tersebut menggunakan pelarut n-heksan, etil asetat, dan air.

Hasil uji memperlihatkan ekstrak mempunyai aktivitas cukup baik dalam menghambat bakteri uji. Bakteri MRSA dapat dihambat oleh fraksi air pinang dengan MIC $256 \mu \mathrm{g} / \mathrm{mL}$; fraksi etil asetat pinang dengan MIC $1.024 \mu \mathrm{g} /$; fraksi n-heksan pinang pada MIC $1.024 \mu \mathrm{g} / \mathrm{mL}$ berturut-turut.

Untuk mengetahui senyawa dalam pinang yang memiliki aktivitas antibakteri dilakukan bioautografi. Hasil bioautografi menunjukkan bahwa bercak noda fraksi air buah pinang dapat menghambat pertumbuhan bakteri jenis MRSA, terbukti dengan zona jernih yang terbentuk setelah perlakuan dan inkubasi selama 24 jam (Gambar 2). Bercak diduga adalah senyawa fenolat. Hal ini didasarkan pada pengujian terhadap noda yang memberikan hasil positif saat disemprot dengan $\mathrm{FeCl}_{3}$. Fenol bereaksi dengan $\mathrm{FeCl}_{3}$ memberikan hasil senyawa warna ungu kehitaman. Senyawa fenol banyak tersebar di tanaman dan merupakan metabolit sekunder karena tidak terlibat langsung dalam jalur metabolisme. Fenol mempunyai aktivitas antibakteri melalui inhibisi senyawa oksidasi yang bereaksi dengan gugus sulfhidril, melalui interaksi nonspesifik dengan protein atau membran sel bakteri. ${ }^{18}$ Mekanisme antimikrob tanin dari buah pinang terhadap MRSA yaitu: 1. Senyawa menguap tanin dapat menginduksi pembentukan yang kompleks dengan enzim atau substrat. Banyak enzim mikrob dalam filtrat atau bentuk yang sudah dimurnikan dihambat apabila ditambahkan tanin, 2. Toksisitas tanin beraksi pada membran mikroorganisme, 3. Pembentukan kompleks logam ion oleh tanin menyebabkan tanin beracun bagi mikrob. ${ }^{19}$

Penggunaan scanning electron microscope (SEM) ditujukan untuk karakterisasi permukaan struktur biomaterial, pengukuran perlekatan sel, dan juga perubahan pada morfologi bakteri. ${ }^{20}$ Hasil SEM menunjukkan fraksi air dari ekstrak etanol buah pinang diduga dapat merusak bagian membran sel atau bagian dalam bakteri, apabila dibandingkan dengan bakteri yang terpapar pada bakteri standar, eritromisin dan juga tetrasiklin, yang mekanisme kerjanya dapat mengganggu sintesis protein bakteri. Gambaran hasil SEM menunjukkan bahwa bakteri yang dipaparkan oleh fraksi tanaman uji mengalami kerusakan selnya. Sel mengerut, menggelembung, sehingga dapat terjadi kerusakan. Eritromisin dan tetrasiklin itu dapat menghancurkan sel, sementara penisilin $\mathrm{G}$ menyebabkan kerusakan pada dinding sel, sel bakteri tampak mengalami permukaan dinding berpori setelah dipapar oleh penisilin G (Gambar 3). Simpulan, fraksi ekstrak etanol buah pinang dapat menghambat pertumbuhan MRSA.

\section{Ucapan Terima Kasih}

Penulis mengucapkan terima kasih kepada semua pihak atas bantuan sehingga penelitian ini dapat terlaksana. Penulis juga mengucapkan terima kasih kepada Sekolah Tinggi Ilmu Kesehatan Jenderal Achmad Yani Cimahi dan Sekolah Farmasi Institut Teknologi Bandung atas fasilitas dan sarana prasarana penelitian.

\section{Daftar Pustaka}

1. WHO. Indonesia Health Profile, 2010. Geneva: WHO Statictics; 2010.

2. Allegranzi B, Nejad SB, Combescure C, Graafmans W, Attar H, Donaldson L, dkk. Burden of endemic health care-associated infections more common in developing countries; systematic review and metaanalysis. Lancet. 2011;377(9761):228-41.

3. Costelloe C, Metcalfe C, Lovering A, Mant D, Hay AD. Effect of antibiotic prescribing in primary care on antimicrobial resistance in individual patients: systematic review and 
meta-analysis. BMJ. 2010;340(1):1-11.

4. Kang CI, Kim SH, Park WB, Lee KD, Kim HB, Kim EC, dkk. Bloodstream infections caused by antibiotic-resistant gram-negative bacilli: risk factors for mortality and impact of inappropriate initial antimicrobial theraphy on outcome. Antimicrob Agents Chemother. 2005;49(2):760-6.

5. Tenover FC. Mechanisms of antimicrobial resistance in bacteria. Am J Med. 2006;119 (6A):S3-10.

6. Onanuga A, OyiAR, Onaolapo JA. Prevalence and susceptibility pattern of methicillin resistant Staphylococcus aureus isolates among healthy women in Zaria, Nigeria. Afr J Biotechnol. 2005;4(11):1321-4.

7. Fridkin SK, Hageman JC, Morrison M, Sanza LT, Como-Sabetti K, Jernigan JA, dkk. Methicillin-resistant Staphylococcus aureus disease in three communities. N Engl J Med. 2005:352(14):1436-44.

8. Arias CA, Murray BE. Antibiotic resistant bugs in the $21^{\text {st }}$ century-a clinical super challenge. N Engl J Med. 2009;360(5):43943.

9. Liu GY. Molecular pathogenesis of Staphylococcus aureus infection. Pediatr Res. 2009;65(5):71-7R.

10. Aarestrup FM. Antimicrobial resistance in bacteria of animal origin. Emerg Infect Dis. 2006;12(7):1180-1.

11. Friedman M. Overview of antibacterial, antitoxin, antiviral, and antifungal activities of tea flavonoids and teas. Mol Nutr Food Res. 2007;51(1):116-34.

12. Jager S, Beffert M, Hoppe K, Nadberezny D, Frank B, Scheffler A. Preparation of herbal tea as infusion or by maceration at room temperature using mistletoe tea as an example. Sci Pharma. 2011;79(1):145-55.

13. Wang JL, Wang JT, Sheng WH, Chen YC, Chang SC. Nosocomial methicillin-resistant Staphylococcus aureus (MRSA) bacteremia in Taiwan: mortality analyses and the impact of vancomycin, $\mathrm{MIC}=2 \mathrm{mg} / \mathrm{L}$, by the broth microdilution method. BMJ Infect Dis. 2010;10(159):1-7.

14. CLSI. Methods for dilution antimicrobial susceptibility tests for bacteria that grow aerobically; approved standard. CLSI Document Guidelines. 2009;29(2):15-8.

15. Choma I. The use of thin-layer chromatography with direct bioautography for antimcrobial analysis. LCCG Europe. 2005;18(9):482.

16. Kalab M, Yang AF, Chabot D. Conventional scanning electron microscope of bacteria. Infocus Royal Microscope Society 2008 [diunduh 16 Juli 2013]. Tersedia dari: http:// www.rms.org.uk.

17. Lingappa A, Nappalli D, Sujatha GP, Shiva PS. Areca nut: to chew or not to chew? E J Dent. 2011;1(3):46-50.

18. Nitiema LW, Savadogo A, Simpore J, Dianou D, Traore AS. In vitro antimicrobial activity of some phenolic compunds (coumarin and quercentin) againts gastroenteritis bacterial strains. Int J Microbiol Res. 2012;3(3):183-7.

19. Aliyu AB, Musa AM, Abdullahi MS, Oyewale $\mathrm{O}$, Gwarzo US. Activity of plant extract used in northern Nigerian traditional medicine against methicillin-resistant Staphylococcus aureus (MRSA). Nig J Pharm Sci. 2008; 7(1):1-8.

20. Kenzaka T, Tani K. Scanning electron microscopy imaging of bacteria based on nucleic acid sequences. Appl Environ Microbiol. 2005;71(9):95523-31. 